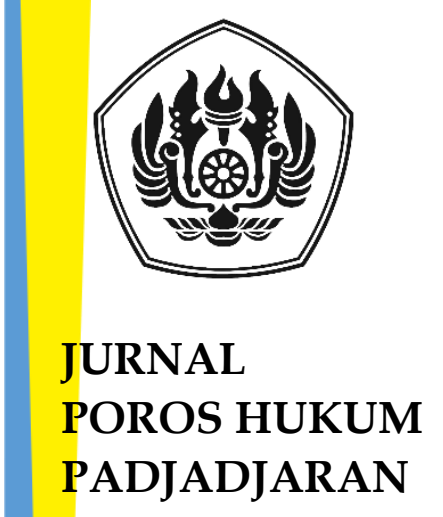

P-ISSN: 2715-7202

E-ISSN: 2715-9418

Artikel diterbitkan:

30 November 2020

DOI:

https:// doi.org/10.23920/jphp .v2i1.290

Halaman Publikasi:

http://jurnal.fh.unpad.ac.id/i ndex.php/JPHP/issue/archive

Diterbitkan oleh:

Fakultas Hukum

Universitas Padjadjaran

\section{PENERBITAN SAHAM BANK BUMD TERBUKA TANPA HAK MEMESAN EFEK TERLEBIH DAHULU DIHUBUNGKAN DENGAN FUNGSI PASAR MODAL SEBAGAI ALTERNATIF PEMBIAYAAN PERUSAHAAN DAN INVESTASI}

\author{
ISSUANCE OF REGIONAL OWNED BANK SHARES \\ WITHOUT PRE-EMPTIVE RIGHTS ASSOCIATED WITH \\ THE CAPITAL MARKET FUNCTION AS AN FINANCING \\ ALTERNATIVE FOR COMPANY AND INVESTMENT
}

\author{
Nia Kania;a R. Kartikasari; ${ }^{\text {b Etty Djukardic }}$
}

\begin{abstract}
ABSTRAK
Salah satu fungsi utama pasar modal adalah sebagai salah satu alternatif pembiayaan bagi perseroan atau investasi, Perseroan terbuka dapat melaksanakan penambahan modal dengan menerbitkan lembar saham baru di pasar modal melalui mekanisme Hak Memesan Efek Terlebih Dahulu atau melalui mekanisme Penambahan Modal Tanpa Hak Memesan Efek Terlebih Dahulu (selanjutnya disebut PMTHMETD). Namun demikian karena mayoritas pemegang saham BUMD adalah Pemerintah Daerah, terdapat ketidakharmonisan antara regulasi yang berlaku di pasar modal untuk aksi korporasi penambahan modal perusahaan dengan regulasi yang berlaku untuk pelaksanaan investasi Pemerintah Daerah sehingga menjadi kendala dalam pelaksanaannya. Penelitian ini bersifat deskriptif analitis dengan menggunakan pendekatan yuridis normatif. Hasil penelitian menunjukkan urgensi pemerintah untuk menyelaraskan regulasi yang berlaku dalam investasi pemerintah daerah dengan aturan yang berlaku di pasar modal mengingat terdapatnya BUMD berstatus perusahaan terbuka, selain itu BUMD berstatus terbuka dalam melakukan aksi korporasi penambahan modal selain PMT HMETD dapat melalui mekanisme HMETD untuk meminimalisir adanya risiko harga eksekusi yang lebih tinggi dari harga pasar. Belum adanya payung hukum yang tegas dalam regulasi investasi pemerintah daerah pada BUMD berstatus perusahaan terbuka tidak mencerminkan asas kepastian hukum, yaitu bagi pemerintah daerah selaku investor dan BUMD itu sendiri sebagai perusahaan terbuka.
\end{abstract}

Kata kunci: BUMD terbuka; kepastian hukum; pasar modal; PMT HMETD.

a Magister Ilmu Hukum Fakultas Hukum Universitas Padjadjaran, Jl. Banda No. 42 Bandung, email: niaganjar@yahoo.com.

b Fakultas Hukum Universitas Padjadjaran, Jalan Raya Bandung Sumedang KM. 21 Jatinangor, email: kartikasari@unpad.ac.id

Fakultas Hukum Universitas Padjadjaran, Jalan Raya Bandung Sumedang KM. 21 Jatinangor, email: etty.djukardi@unpad.ac.id 


\begin{abstract}
One of the main functions of capital market is as an alternative financing for a company or investment, a public company can carry out additional capital by issuing new shares through rights issue or through the mechanism of "Without Pre-emptive Rights" (PMTHMETD). However, because the majority of shareholders are Regional Governments, there is a gap between capital market regulation with Local Government investment regulation, so it becomes an obstacle in its implementation. This research is a descriptive analytical study using a normative juridical approach. The results show the urgency of the government to harmonize applicable regulations in the implementation of local government investment with capital market regulation considering there are Public Listed Regional Owned Company, however Public Listed Regional Owned Company in carrying out corporate actions can increase capital through the "with pre-emptive rights" or HMETD mechanism to minimize the risk of execution price which is higher than the market price. The absence of a firm legal protection in the regulation of local government investment in Public listed Regional Owned Company does not reflect the principle of legal certainty, namely for the local government as an investor and the Regional Owned Company itself as a public listed company.
\end{abstract}

Keywords: capital market; legal certainty; Non Pre-emptive Rights; public listed regional owned company.

\title{
PENDAHULUAN
}

Dalam rangka menunjang pembangunan ekonomi antara lain melalui lembaga perbankan maupun pasar modal, maka seluruh tindakan dalam bidang perekonomian harus berlandaskan pada hukum positif. Pembangunan ekonomi memiliki keterkaitan yang erat dengan pembangunan hukum. Penegakan asas hukum yang baik akan mendukung perkembangan pembangunan ekonomi dengan kata lain pembangunan ekonomi dapat terhambat jika asas-asas hukum tidak diterapkan dengan tepat.

Pembangunan hukum tidak dapat dilepaskan dari pembangunan nasional, sebagaimana Mochtar Kusumaatmadja menyatakan bahwa fungsi hukum merupakan sarana pembaharuan masyarakat. Pergaulan atau hubungan masyarakat merupakan interaksi antar manusia yang saling bergantung dan membutuhkan. Dalam rangka menciptakan hubungan antar manusia dengan baik maka dibutuhkan serangkaian peraturan yang dapat melindungi kepentingannya dan menghormati kepentingan dan hak orang lain sesuai hak dan kewajiban yang ditentukan aturan (hukum). ${ }^{1}$

Tujuan dan fungsi hukum Indonesia bukan hanya memelihara ketertiban, keamanan, dan stabilitas di masyarakat, tetapi juga diarahkan pada cita-cita untuk mencapai kesejahteraan masyarakat Indonesia. ${ }^{2}$ Dengan arah hukum yang ingin memberikan porsi pada pencapaian kesejahteraan. ${ }^{3}$ Tidak adanya penegakan hukum

\footnotetext{
${ }^{1}$ Kusumaatmadja, Mochtar, Sidharta, B. Arief. (2000). Pengantar Ilmu Hukum Suatu Pengenalan Pertama Ruang Lingkup Berlakunya Ilmu Hukum - Buku I. Bandung: Alumni. hlm. 16.

2 Hartono, Sunaryati. (1982). Hukum Ekonomi Pembangunan Indonesia. Bandung: Bina Cipta. hlm. 17.

3 Djumhana, Muhammad. (1994). Hukum Ekonomi Sosial Indonesia. Bandung: Citra Aditya Bakti. hlm. 239.
} 
dan ketertiban dapat menghambat pencapaian masyarakat yang berusaha dan bekerja dengan baik untuk memenuhi kebutuhan hidupnya. Menurut Mochtar Kusumaatmadja, hukum merupakan suatu alat untuk memelihara ketertiban dalam masyarakat dan memiliki sifat yang konservatif. Hukum adalah segenap asas dan kaidah yang berfungsi mengatur anggota masyarakat dalam pergaulan hidupnya serta memelihara ketertiban dalam kelompok masyarakat tersebut. ${ }^{4}$ Artinya, hukum bersifat memelihara dan mempertahankan yang telah tercapai. Kesulitan dalam menggunakan hukum sebagai suatu alat untuk mengadakan perubahan-perubahan kemasyarakatan adalah bahwa kita harus sangat berhati-hati agar tidak munculnya kerugian di dalam masyarakat.

Pembangunan ekonomi yang tidak lepas dari aktivitas bisnis memerlukan dana sebagai modal dalam memulai usaha atau melaksanakan kegiatan operasional perusahaan. Modal (equity) perusahaan berasal dari pendiri dan apabila suatu perusahaan tersebut berbentuk Perseroan Terbatas maka modal dimaksud dapat berasal dari pemegang saham maupun berupa utang (loan) yang berasal dari satu atau lebih kreditur. ${ }^{5}$

Modal memiliki peran sebagai alat dalam menjalankan kegiatan usaha perusahaan. Oleh karena itu, para pelaku usaha berupaya mencari tambahan modal guna meningkatkan usaha dan menjamin kelangsungan hidup perusahaan, termasuk lembaga perbankan. Pada umumnya lembaga perbankan berfungsi sebagai badan usaha yang menghimpun dana masyarakat dan menyalurkan dana tersebut dalam bentuk kredit. Selain fungsi-fungsi tersebut, lembaga perbankan juga diperlukan untuk menjaga stabilitas maupun mendorong pertumbuhan ekonomi bangsa.

Kemampuan bank dalam mencari sumber-sumber dana untuk kebutuhan modal sangat mempengaruhi kondisi stabilitas keuangan bank. Dalam hal bank gagal mengelola dana miliknya maka bank memiliki risiko mengalami kebangkrutan atau likuidasi. Modal bank merupakan salah satu hal utama yang wajib dikelola agar dapat menjamin pelaksanaan ataupun ekspansi kegiatan usaha bank. Hal tersebut diatur dalam ketentuan Undang-Undang Nomor 10 Tahun 1998 Tentang Perubahan Atas

\footnotetext{
4 Salman, Otje, Damian, Eddy. (2011). Kumpulan Karya Tulis: Mochtar Kusumaatmadja Konsep-Konsep hukum dalam Pembangunan, Bandung: Alumni. hlm. 13.

5 Sjahdeini, Sutan Remy. (2016). Sejarah, Asas, dan Teori Hukum Kepailitan. Jakarta: Kencana. hlm. 393.
} 
Undang-Undang Nomor 7 Tahun 1992 Tentang Perbankan (selanjutnya disebut UU Perbankan) juga mengatur kewajiban bank untuk memelihara kecukupan modal bank.

Kecukupan modal bank merupakan salah satu indikator penilaian tingkat kesehatan bank yang ditentukan oleh Otoritas Jasa Keuangan. Penilaian tingkat kesehatan bank diperlukan karena bank menerima dan mengelola dana masyarakat sehingga bank wajib memelihara atau meningkatkan tingkat kesehatan bank dengan menerapkan prinsip kehati-hatian dan manajemen risiko dalam melaksanakan kegiatan usaha. Berdasarkan ketentuan Pasal 6 Peraturan Otoritas Jasa Keuangan nomor 4/POJK.03/2016 tentang Penilaian Tingkat Kesehatan Bank Umum disebutkan bahwa faktor-faktor penilaian tingkat kesehatan bank yang dilakukan oleh Otoritas Jasa Keuangan meliputi profil risiko (risk profile), Good Corporate Governance (GCG), rentabilitas (earnings) permodalan (capital). Khusus penilaian terhadap faktor permodalan meliputi tingkat kecukupan modal dan pengelolaan permodalan.

Pasar modal dipandang sebagai salah satu sarana yang efektif untuk mempercepat pembangunan suatu negara. ${ }^{6}$ Adanya pasar modal mengakibatkan perusahaanperusahaan akan lebih mudah memperoleh dana sehingga kegiatan ekonomi di berbagai sektor dapat ditingkatkan. ${ }^{7}$ Hal ini terjadi karena pasar modal merupakan wahana yang dapat menggalang pengerahan dana jangka panjang dari masyarakat untuk disalurkan ke sektor-sektor yang produktif. Apabila pengerahan dana masyarakat melalui lembaga-lembaga keuangan maupun pasar modal dapat berlangsung dengan baik maka kebutuhan dana pembangunan yang bersumber dari luar negeri akan semakin berkurang. Pasar modal juga berfungsi sebagai investasi, pemerataan pendapatan melalui pemberian dividen perusahaaan, meningkatkan pendapatan Negara melalui penerimaan pajak atas dividen serta indikator perekonomian Negara terkait dengan kegiatan dan volume jual beli efek di pasar modal.

Berdasarkan Undang-Undang nomor 8 tahun 1995 tentang Pasar Modal (selanjutnya disebut UU Pasar Modal) yang disebut dengan efek adalah surat berharga, yaitu surat pengakuan utang, surat berharga komersial, saham, obligasi, tanda bukti utang, unit penyertaan kontrak investasi kolektif, kontrak berjangka atas efek, dan setiap derivatif dari efek. Sebagaimana disebutkan dalam Pasal 1 angka 7 Undang-Undang

\footnotetext{
${ }^{6}$ Rokhmatussa'dyah, Ana, Suratman. (2018). Hukum Investasi dan Pasar Modal, Cetakan ke-5. Jakarta: Sinar Grafika. hlm. 165.

7 Rokhmatussa'dyah, Ana, Suratman. Op.Cit., hlm. 166.
} 
Nomor 40 tahun 2007 tentang Perseroan Terbatas (selanjutnya disebut UU PT) disebutkan bahwa Perseroan Terbuka adalah Perseroan Publik atau Perseroan yang melakukan penawaran umum saham, sesuai dengan ketentuan peraturan perundangundangan di bidang pasar modal. Adapun Perusahaan Publik adalah Perseroan yang sahamnya telah dimiliki sekurang-kurangnya oleh 300 (tiga ratus) pemegang saham dan memiliki modal disetor sekurang-kurangnya Rp 3.000.000.000,00 (tiga miliar rupiah) atau suatu jumlah pemegang saham dan modal disetor yang ditetapkan dengan Peraturan Pemerintah. ${ }^{8}$

Pasar modal memiliki peran penting dalam perekonomian suatu negara karena memiliki dua fungsi, yaitu9:

a. Fungsi ekonomi yaitu menyediakan fasilitas atau wahana yang mempertemukan dua kepentingan yaitu pihak investor dan pihak yang memerlukan dana.

b. Fungsi keuangan yaitu memberikan kemungkinan dan kesempatan memperoleh imbalan (return) bagi pemilik dana sesuai dengan karakteristik investasi yang dipilih. Emiten sebagai pihak yang memerlukan dana dapat memperoleh dana dari investor dengan cara melaksanakan penawaran umum (Public Offering) dan penawaran terbatas (Private Placement). Penawaran Umum ini, dilakukan dengan cara menerbitkan saham atau efek bersifat ekuitas yang ditawarkan melalui pasar modal agar dapat dibeli secara bebas oleh investor. Investor yang memilih cara seperti ini akan menjadi pemegang saham pada perusahaan terbuka milik emiten.

Keuntungan yang diharapkan dari berinvestasi saham adalah memperoleh return berupa capital gain dan deviden. Selain keuntungan, faktor resiko juga harus diperhatikan oleh investor apabila ingin berinvestasi saham. Pada umumnya resiko yang harus diperhatikan investor adalah resiko capital loss dan resiko likuiditas ${ }^{10}$. Perseroan Terbuka dapat melaksanakan penambahan modal melalui mekanisme Penambahan Modal dengan Hak Memesan Efek Terlebih Dahulu (right issue) atau melalui mekanisme Penambahan Modal Tanpa Hak Memesan Efek Terlebih Dahulu (selanjutnya disebut PMTHMETD). Perbedaan mendasar antara rights issue dengan PMTHMETD yaitu pada PMTHMETD, pemegang saham existing tidak memiliki hak khusus untuk didahulukan

\footnotetext{
8 UU Pasar Modal Pasal 1 angka 22

9 Mustofa, Alim, Cahyono, Hendry. (2014). “Analisis Kontribusi Pasar Modal sebagai Sarana Pendanaan Usaha bagi Perusahaan serta multiplier Effect yang ditimbulkannya dalam perekonomian". Jurnal Pendidikan dan Ekonomi UNESA, Vol. 2 No. 3, 5.

${ }^{10}$ Sujatmiko, Bagus, Suryanti, Nyulistiowati. (2017) “Perlindungan Hukum bagi Investor pada Perusahaan Terbuka yang Pailit Ditinjau dari Hukum Kepailitan". Jurnal Bina Mulia Hukum, Vol. 2 No. 1, 16-17.
} 
guna membeli saham baru yang diterbitkan. Pemegang saham yang diberikan hak untuk membeli saham baru telah ditentukan terlebih dahulu. Beberapa tujuan aksi penerbitan saham baru melalui PMTHMETD antara lain penggalangan dana yang dapat digunakan untuk berbagai kebutuhan finansial perusahaan seperti ekspansi bisnis dan pembayaran hutang; adanya investor besar yang baru akan masuk ke dalam perusahaan; serta merekrut investor strategis yang dapat membantu kegiatan usaha dan perkembangan perusahaan. Sedangkan pada right issue atau HMETD pelaku pasar memperoleh hak yang sama untuk membeli saham baru yang akan diterbitkan. Hak untuk membeli saham baru disebut dengan Hak Memesan Efek Terlebih Dahulu (selanjutnya disebut HMETD). HMETD diperdagangkan di bursa pada kurun waktu tertentu. Pada saat HMETD diperdagangkan, pelaku pasar dapat membeli HMETD pihak lain, menjual HMETD milik sendiri atau menebus hak tersebut menjadi saham baru yang akan diterbitkan.

Salah satu contoh BUMD berstatus perusahaan terbuka yang memerlukan dukungan permodalan yang berkesinambungan adalah Perbankan BUMD yang telah melaksanakan IPO (Initial Public Offering). Sebagai suatu lembaga perbankan berstatus BUMD yang kemudian mendaftarkan efeknya di pasar modal sehingga menjadi berbentuk terbuka tentu memiliki kebutuhan terhadap modal dalam rangka ekspansi bisnis atau menjaga rasio kecukupan modal (Capital Adequency Ratio). Dalam hal diperlukan penguatan struktur permodalan melalui pasar modal, maka RUPS wajib memberikan persetujuan atas corporate action untuk menerbitkan saham baru, apakah penambahan modal dimaksud dilakukan dengan atau tanpa hak memesan efek terlebih dahulu.

Hal yang paling mendasar dalam penambahan modal melalui mekanisme PMT HMETD adalah terdapat rentang waktu 2 (dua) tahun sejak disetujui dalam RUPS, sehingga pemegang saham dalam hal ini Pemerintah Daerah dapat melakukan tahapan birokrasi yang diperlukan mulai dari penyusunan Perda Investasi sampai dengan Perda APBD untuk penganggarannya. Sedangkan apabila RUPS memutuskan penambahan modal dilakukan dengan hak memesan efek terlebih dahulu, hal yang mendasar adalah pengefektifan setoran modal harus dilakukan dalam waktu bersamaan setelah diperolehnya pernyataan efektif oleh Otoritas Jasa Keuangan sebagaimana diatur dalam POJK Nomor 14/POJK.04/2019 Tentang Perubahan Atas Peraturan Otoritas Jasa 
Keuangan nomor 32/POJK.04/2015 Tentang Penambahan Modal Perusahaan Terbuka Dengan Memberikan Hak Memesan Efek Terlebih Dahulu.

Harga saham dalam pasar modal bersifat dinamis sehingga harga saham cenderung berubah-ubah dipengaruhi oleh faktor permintaan dan penawaran. Fluktuasi harga saham merupakan tantangan bagi Pemerintah Daerah yang mana jika pada rentang waktu yang telah ditentukan dalam POJK Penambahan Modal Perusahaan Terbuka Dengan HMETD harga saham di pasar modal lebih rendah daripada harga saham yang telah disetujui pada saat pelaksanaan RUPS penerbitan saham baru maka setoran modal melalui PMT HMETD sebagaimana kajian hukum yang diperoleh disarankan untuk ditunda pelaksanaannya. Dalam hal ini PMT HMETD yang memiliki rentang waktu 2 (dua) tahun sejak disetujui oleh RUPS memiliki kemungkinan fluktuasi harga yang lebih besar daripada right issue, di sisi lain PMT HMETD memberikan rentang waktu yang cukup bagi pemerintah daerah untuk melakukan kajian, penyusunan perda, penganggaran, dan hal lain yang diperlukan dalam birokrasi nya.

Obyek dalam penelitian ini membahas mengenai efektifitas PMT HMETD dalam upaya peningkatan permodalan BUMD terbuka dan dampak perubahan harga saham dalam kegiatan penambahan modal tanpa hak memesan efek terlebih dahulu yang dilakukan oleh bank BUMD terbuka. Mayoritas pemegang saham BUMD adalah Pemerintah Daerah sehingga meskipun aksi korporasi penerbitan saham baru sudah diatur secara jelas dalam POJK, aksi Pemerintah Daerah selaku pemegang saham BUMD terbuka untuk melakukan investasi melalui pasar modal patut mengikuti berbagai kajian yang dilakukan diantaranya kajian kelayakan investasi, aspek keuangan daerah, penilaian wajar dan kajian hukum. Penentuan harga saham yang wajar (reasonable) merupakan masalah krusial bagi Pemerintah Daerah selaku pemegang saham karena Pemerintah Daerah wajib menerapkan prinsip-prinsip akuntabilitas dalam pengelolaan keuangan daerah. Rentang waktu yang cukup panjang selama 2 (dua) tahun untuk pengefektifan dana setoran modal menghadapi tantangan jika harga saham pada pasar modal lebih rendah daripada harga saham yang telah diputuskan dalam RUPS sebagaimana kajian aspek hukum yang diperoleh oleh Pemerintah Daerah.

Berdasarkan hal tersebut, penulis tertarik untuk melakukan penelitian mengenai bagaimana praktik penambahan modal sebuah bank BUMD terbuka melalui penerbitan lembar saham baru yang dilakukan dengan mekanisme tanpa hak memesan efek terlebih dahulu (PMT HMETD) dihubungkan dengan fungsi pasar modal sebagai 
alternatif pembiayaan perusahaan dan investasi agar terciptanya asas kepastian hukum baik bagi Pemerintah Daerah sebagai Investor maupun bagi BUMD yang berstatus perusahaan terbuka dalam aksi korporasi yang dilakukannya untuk penambahan modal tanpa menghambat kegiatan bisnis dan meminimalisir risiko hukum.

\section{METODE PENELITIAN}

Metode pendekatan yang digunakan adalah metode pendekatan yuridis normatif, yaitu suatu metode hukum yang dilakukan dengan meneliti bahan pustaka atau data sekunder. ${ }^{11}$ Penelitian ini menggunakan metode yang menekankan pada norma hukum, di samping juga berusaha menelaah kaidah-kaidah hukum yang berlaku dalam masyarakat. ${ }^{12}$ Penelitian ini mengkaji dan menganalisis penerbitan saham oleh bank berbentuk Badan Usaha Milik Daerah (BUMD) terbuka tanpa hak memesan efek terlebih dahulu terkait dengan fungsi pasar modal sebagai alternatif pembiayaan perusahaan dan investasi. Penelitian yang dilakukan adalah deskriptif analitis, yaitu dengan menggambarkan suatu objek permasalahan yang berupa fakta-fakta dalam mengkaji peranan Hukum di bidang Pasar Modal. Selanjutnya dihubungkan dengan teori-teori, asas-asas, dan kaidah-kaidah hukum yang diperoleh dari studi kepustakaan sehingga diperoleh jawaban atas permasalahan yang diidentifikasi.

Tahapan penelitian dilakukan melalui 2 (dua) tahapan yaitu penelitian kepustakaan terhadap sumber data primer yang sifatnya mengikat masalah- masalah yang akan diteliti seperti asas-asas hukum, norma dasar Pancasila, UUD 1945, Kitab Undang-Undang Hukum Perdata, UU PT, UU Perbankan, UU Pemerintah Daerah, Peraturan Pemerintah Tentang Investasi Pemerintah, Peraturan Pemerintah Tentang Badan Usaha Milik Daerah, POJK Penambahan Modal Perusahaan Terbuka Tanpa HMETD. Sumber data sekunder yaitu bahan hukum yang memberikan penjelasan terhadap bahan hukum primer, yaitu hasil karya para ahli hukum berupa buku-buku, pendapat-pendapat para sarjana yang berhubungan dengan usulan penelitian ini. ${ }^{13}$ serta bahan hukum tersier, bahan hukum yang memberikan petunjuk atau penjelasan bermakna bahan hukum primer dan/atau bahan hukum sekunder yaitu kamus hukum dan lain-lain. ${ }^{14}$ Kedua sumber data dari penelitian lapangan diambil dengan melihat

\footnotetext{
${ }^{11}$ Soekanto, Soerjono, Mamudji, Sri. (2009). Penelitian Hukum Normatif. Jakarta: PT. Raja Grafindo Persada. hlm. 13.

12 Idem

${ }^{13}$ Mulyana, Dedy. (2003) Metodologi Penelitian Kualitatif. Bandung: Remaja Rosdakarya. hlm. 74.

${ }^{14} \mathrm{Idem}, \mathrm{hlm} .53$.
} 
fakta-fakta yang terjadi dalam praktiknya terkait penerbitan saham baru Tanpa Hak Memesan Efek Terlebih Dahulu (PMT HMETD) untuk mencari data primer yaitu sebagai pelengkap atau pendukung penelitian kepustakaan. ${ }^{15}$

\section{PEMBAHASAN}

Dalam rangka meningkatkan akses pembiayaan dari pasar modal bagi emiten atau perusahaan publik sehingga dapat membuat pasar modal sebagai pilihan alternatif sumber pembiayaan yang lebih kompetitif bagi dunia usaha dan mendorong peningkatan kepemilikan publik secara lebih meluas, persyaratan penambahan modal Tanpa HMETD, telah diatur dalam POJK Penambahan Modal Perusahaan Terbuka Tanpa HMETD, dengan ketentuan yang diatur pada Pasal 2 ayat (1) POJK Penambahan Modal Perusahaan Terbuka Tanpa HMETD yang menyebutkan bahwa:

“Perusahaan Terbuka dapat menambah modal tanpa memberikan HMETD kepada pemegang saham sebagaimana diatur dalam peraturan di sektor Pasar Modal yang mengatur mengenai HMETD, baik untuk memperbaiki posisi keuangan maupun selain untuk memperbaiki posisi keuangan Perusahaan Terbuka. “

Selanjutnya Pasal 2 ayat (2) POJK PMT HMETD menyebutkan bahwa:

“Penambahan modal Perusahaan Terbuka tanpa memberikan HMETD sebagaimana dimaksud pada ayat (1) wajib terlebih dahulu memperoleh persetujuan RUPS."

Selanjutnya Pasal 2 ayat (3) POJK PMT HMETD menyebutkan bahwa:

“RUPS sebagaimana dimaksud pada ayat (2) wajib dilakukan sesuai dengan ketentuan sebagaimana diatur dalam Peraturan Otoritas Jasa Keuangan yang mengatur mengenai Rencana dan Penyelenggaraan RUPS Perusahaan Terbuka dan anggaran dasar Perusahaan Terbuka."

Berdasarkan ketentuan Pasal 3 POJK PMT HMETD, untuk memperbaiki posisi keuangan dapat dilakukan sepanjang memenuhi kondisi sebagai berikut:

a) Perusahaan Terbuka adalah bank yang menerima pinjaman dari Bank Indonesia atau lembaga pemerintah lain yang jumlahnya lebih dari 100\% (seratus persen) dari

${ }^{15}$ Idem, hlm. 99. 
modal disetor atau kondisi lain yang dapat mengakibatkan restrukturisasi bank oleh instansi Pemerintah yang berwenang;

b) Perusahaan Terbuka selain bank yang mempunyai modal kerja bersih negatif dan mempunyai liabilitas melebihi $80 \%$ (delapan puluh persen) dari aset Perusahaan Terbuka tersebut pada saat RUPS yang menyetujui penambahan modal tanpa memberikan HMETD;

c) Perusahaan Terbuka tidak mampu memenuhi kewajiban keuangan pada saat jatuh tempo kepada pemberi pinjaman yang tidak terafiliasi sepanjang pemberi pinjaman yang tidak terafiliasi tersebut menyetujui untuk menerima saham atau obligasi konversi Perusahaan Terbuka untuk menyelesaikan pinjaman tersebut."

Penambahan modal perusahaan terbuka melalui PMT HMETD selain untuk memperbaiki posisi keuangan hanya dapat dilakukan paling banyak 10\% (sepuluh persen) dari modal disetor yang tercantum dalam perubahan anggaran dasar yang telah diberitahukan dan diterima Menteri yang berwenang pada saat pengumuman RUPS, dimana untuk PMT HMETD selain dalam rangka program kepemilikan saham dilakukan dalam kurun waktu 2 (dua) tahun sejak RUPS, sedangkan PMT HMETD dalam rangka kepemilikan saham dilakukan dalam kurun waktu 5 (lima) tahun sejak RUPS.

Adapun tahapan penambahan modal bank BUMD Terbuka melalui mekanisme PMT HMETD yaitu diawali dengan konsultasi dan sosialisasi terkait penambahan modal BUMD terbuka pasca IPO kepada lembaga/instansi terkait. Namun dalam praktiknya ditemukan ketidakharmonisan antara peraturan pasar modal dengan regulasi yang mengatur mengenai investasi Pemerintah Daerah, sehingga untuk itu diperlukan berbagai kajian diantaranya meliputi hal-hal sebagai berikut:

\section{Keselarasan Peraturan Perundang-Undangan}

Kajian mengenai keselarasan dari ketentuan peraturan perundang-undangan yang dilakukan pada pokoknya disampaikan bahwa:

a. Pemda dapat melakukan penyertaan modal pada BUMD terbuka dan atau melakukan penambahan penyetoran modal pada BUMD terbuka;

b. Penyertaan modal Pemda pada BUMD terbuka dilaksanakan berdasarkan nilai wajar melalui hasil analisis penasihat investasi. Mengingat saham BUMD terbuka 
diperdagangkan di Bursa Efek Indonesia maka harga wajar penyertaan modal tersebut dapat saja harga pasar atas saham BUMD terbuka tersebut;

c. Sebelum melaksanakan penyertaan modal pada BUMD terbuka, Pemda harus melakukan sejumlah tindakan yang dipersyaratkan dalam UU dan peraturan lainnya;

d. BUMD terbuka wajib mengikuti POJK dan SK Direksi PT Bursa Efek Indonesia sehingga harga pelaksanaan saham baru yang ditawarkan adalah rata-rata harga penutupan saham (harga pasar) selama 25 Hari Bursa berturut-turut sebelum iklan RUPS.

e. Apabila harga wajar lebih rendah daripada harga pelaksanaan saham baru maka transaksi ditunda terlebih dahulu. Apabila harga wajar sama atau di atas harga pelaksanaan saham baru maka transaksi dapat dilaksanakan;

f. Salah satu sumber modal BUMD adalah penyertaan modal Pemda dan agio sahamnya dan ini berarti harga saham BUMD dapat dijual di atas harga nominal;

g. Apabila Pemda sudah memiliki peraturan daerah (Perda) tentang penyertaan modal sebelumnya maka Perda tersebut tidak perlu direvisi sepanjang nilai pelaksanaan penyertaan modal tersebut tidak melebihi nilai yang sudah tercantum di Perda sebelumnya. Apabila akan melebihi maka Perda tersebut perlu direvisi.

h. Pelaksanaan investasi Pemda tidak harus dilakukan oleh BLUD;

i. Sepanjang Pemda sudah melaksanakan aturan-aturan yang berkaitan dengan pelaksanaan investasi Pemda maka kecil kemungkinan Pemda akan melakukan tindakan yang merugikan keuangan Daerah;

j. Pemerintah sudah menyiapkan pedoman pencatatan penyertaan modal Pemda pada BUMD dan mengeluarkan contoh pencatatan penyertaan modal Pemda. Oleh karena itu, Pemda seharusnya tidak memiliki keraguan lagi bagaimana caranya mencatat penyertaan modal di atas nilai nominal.

k. Mempertimbangkan hal-hal yang disebutkan terdahulu maka Pemda seharusnya tidak memiliki keraguan untuk melaksanakan penyertaan modal pada BUMD terbuka dan segera mempersiapkan dokumen-dokumen yang dibutuhkan atau langkah-langkah yang diperlukan untuk merealisasikannya. 


\section{Aspek Keuangan Daerah}

Sebagai upaya mendapatkan kajian yang lebih komperehensif dari sisi Keuangan Daerah atas aksi korporasi BUMD terbuka melalui PMT HMETD, Pemerintah Daerah mengajukan permohonan kajian kepada instansi terkait agar pelaksanaan penyertaan modal Pemerintah Daerah pada BUMD terbuka sesuai dengan ketetuan peraturan perundang-undangan yang berlaku. Kajian ini antara lain untuk meyakini bagaimana PMT HMETD dapat dilaksanakan. Pada pokoknya hasil kajian tersebut yaitu:

a. Perlakuan akuntansi atas akuntansi Pemda mengacu pada Peraturan Menteri Keuangan Nomor 223/PMK.05/2016 Nomor 6 dan lampirannya poin 26, untuk akuntansi investasi jangka panjang permanen dengan metode ekuitas.

b. Pemerintah Daerah sebagai pemegang saham membentuk satuan tugas atau panitia pengelolaan dan pengawasan penyertaan modal di BUMD terbuka.

c. Berkonsultasi lebih intensif dengan Otoritas Jasa Keuangan (OJK) dan Bursa Efek Indonesia sebagai Institusi yang lebih kompeten menangani permasalahan terkait Penyertaan Modal Tanpa Hak Memesan Efek Terlebih Dahulu (PMT HMETD).

\section{Aspek Hukum}

Sebagai upaya mendapatkan kajian yang lebih komperehensif dan memperoleh kepastian dari sisi hukum atas isu strategis terkait PMT HMETD BUMD terbuka, Pemerintah Daerah telah mengajukan kajian hukum kepada instansi terkait sehingga rencana penyertaan modal Pemerintah Daerah pada BUMD terbuka sesuai dengan ketentuan peraturan perundang-undangan. Kajian hukum ini dilakukan antara lain untuk meyakini bagaimana PMT HMETD dapat dilaksanakan, karena adanya ketidakharmonisan regulasi khususnya untuk menentukan nilai harga pembelian. Pada pokoknya hasil kajian tersebut adalah sebagai berikut:

a. Rencana penambahan modal BUMD terbuka melalui mekanisme Penambahan Modal Tanpa Hak Memesan Efek Terlebih Dahulu, dapat dilakukan sesuai tahapantahapan PMT HMETD yang ditentukan dalam peraturan perundang-undangan yang berlaku, dengan ketentuan penambahan modal maksimal $10 \%$ dari modal disetor yang tercantum dalam Anggaran Dasar, yang pelaksanaan penambahan modalnya dilakukan paling lama 2 (dua) tahun, setelah mendapatkan persetujuan RUPS yang tahapan RUPS-nya mengacu kepada POJK No. 10/POJK/2017 sedangkan untuk penentuan harga saham mengacu kepada Peraturan No.1-A, Lampiran Keputusan 
Direksi PT Bursa Efek Indonesia No. Kep- 00001/BEI/01-2014 tanggal 20 Januari 2014 tentang Pencatatan Saham dan Efek Bersifat Ekultas Selain Saham yang Diterbitkan oleh Perusahaan Tercatat.

b. Rencana Penyertaan Modal Daerah dapat dilaksanakan sepanjang telah dilakukan Analisis investasi yang dilakukan oleh penasehat investasi daerah yang ditunjuk oleh Gubernur dan telah disetujui oleh Gubernur dengan syarat Anggaran Pendapatan dan Belanja Daerah diperkirakan surplus, selanjutnya dianggarkan dalam Perda APBD serta didalam Perda Penyertaan Modal. Didalam Analisis investasi yang dilakukan oleh penasehat investasi daerah agar memuat kajian mengenai batas minimal perolehan tembar saham yang akan diperoleh oleh Pemerintah Daerah serta pencatatan agio yang diperoleh.

c. Apabila kondisi harga saham pada saat akan dilakukan penempatan berada dibawah harga saham yang disetujui/ditetapkan dalam RUPS, maka sebaiknya Pemerintah Daerah menunda terlebih dahulu penyertaan/penempatan modal karena perolehan jumlah lembar saham akan lebih kecil dibandingkan dengan nilai rupiah yang disetorkan oleh Pemerintah Daerah, sehingga porsi kepemilikan tidak sesuai dengan yang diharapkan, Penempatan/Penyetoran Modal baru dapat dilaksanakan apabila kondisi harga saham pada saat akan dilakukan penempatan sama atau diatas harga saham yang disetujui/ditetapkan dalam RUPS selama jangka waktu 2 (dua) tahun.

d. Hasil Kajian Penasehat Investasi yang ditunjuk oleh Pemegang Saham Pengendali dapat dijadikan rujukan oleh Pemegang Saham Pemerintah Daerah lainnya dengan cara Pemerintah Daerah lainnya menundukkan diri terhadap Hasil Kajian Penasehat Investasi yang ditunjuk oleh Pemegang Saham Pengendali untuk rencana Penyertaan Modal kepada BUMD terbuka, yang dituangkan dalam bentuk Keputusan Gubernur/Bupati/Walikota mengingat objek analisisnya sama yaitu rencana Penyertaan Modal kepada BUMD terbuka melalui mekanisme PMT HMETD.

\section{Kelayakan Investasi}

Berkaitan dengan kajian Penasehat Investasi Pemerintah Daerah dalam hal menyusun telaahan atas usulan Pemerintah Daerah untuk penyertaan modal kepada BUMD terbuka pada Perubahan Anggaran Pendapatan dan Belanja Daerah (APBD). Kajian ini disusun untuk mengawal pemerintah daerah yang akan melakukan investasi, dimana pada pokoknya hasil kajian tersebut adalah: 
a. Segi Kelayakan

1) Bank Daerah yang menjadi bank Umum dengan layanan yang luas;

2) Selama tiga tahun berturut-turut 2015-2017 menghasilkan perolehan laba yang besarnya sangat material;

3) Secara ratio keuangan dan NPL menunjukkan nilai yang baik dan berisiko rendah;

4) Perusahaan telah menunjukkan komitmennya untuk membagikan dividen kepada para pemegang saham meningkat setiap tahunnya;

5) BUMD terbuka dalam memberikan Imbal hasil dalam bentuk dividen, memiliki nilai imbal hasil diatas bunga perbankan secara umum.

b. Segi Portofolio

1) Pendapatan bunga yang terus meningkat dan beban bunga yang stagnan mencerminkan bahwa pengelolaan portofolio BUMD terbuka sudah berhasil;

2) Portofolio perkreditan BUMD terbuka 2015-2017 terlihat sehat, dengan tingkat NPL (gross) yang jauh lebih baik dibandingkan industri perbankan Indonesia;

3) Portofolio BUMD terbuka yang berasal dari pemberian kredit dan penerimaan DPK sudah dikelola secara baik yang terbukti dengan semakin besarnya pendapatan bunga bersih, yang berasal dari pengurangan pendapatan bunga oleh beban bunga;

4) Portofolio kredit BUMD terbuka didominasi oleh kredit konsumer, yang merupakan kredit konsumtif dan berisiko rendah karena dijamin oleh gaji yang diterima oleh penerima kredit. Kredit ini terus bertumbuh, tetapi akselerasi pertumbuhannya di tahun 2017 telah mengalami penurunan jika dibandingkan dengan tahun-tahun sebelumnya. Oleh karena itu perlu diambil tindakan yang tepat bukan saja untuk meningkatkan jumlahnya tetapi akselerasinya. Secara umum portofolio BUMD terbuka ini merupakan portofolio yang baik dan penyumbang terbesar pendapatan bunga BUMD terbuka;

5) Portofolio DPK BUMD terbuka ini juga mengalami pertumbuhan yang baik, meskipun pertumbuhannya pada tahun 2016 dan 2017 didominsasi oleh Deposito sehingga rasio CASA menjadi menurun pada tahun 2016 dan 2017. Namun demikian secara umum portofolio ini sudah baik, hanya saja secara jangka panjang perlu diupayakan agar rasio CASA meningkat di atas 50\% yang berarti DPK yang dikelola BUMD terbuka menjadi semakin murah. 


\section{c. Segi Risiko}

1) BUMD terbuka dalam menyalurkan kreditnya didominasi oleh kredit konsumer dan ritel, dengan berdasarkan sumber pembayaran yang jelas dan lebih dapat dipastikan sehingga BUMD terbuka berisiko rendah dalam kaitan NPL guna menjamin kesehatan bank dan menjaga aspek prudential;

2) Berdasarkan kriteria yang ada pada POJK no 4/POJK.03/2016 Tentang Penilaian Tingkat Kesehatan Bank Umum, pasal 9 ayat 4, BUMD terbuka (bank only) merupakan bank yang Peringkat Komposit 2 (PK-2) sebagaimana dimaksud pada ayat (2) huruf b mencerminkan kondisi Bank yang secara umum sehat sehingga dinilai mampu menghadapi pengaruh negatif yang signifikan dari perubahan kondisi bisnis dan faktor eksternal lainnya;

3) Berdasarkan self assestment konsolidasi BUMD terbuka memiliki peringkat yang sama, ketika kita membandingkan self assestment bank only, dengan peringkat komposit 2 (PK 2), dapat diartikan bahwa BUMD terbuka merupakan bank yang secara umum, sehingga dinilai mampu menghadapi pengaruh negatif yang signifikan dari perubahan kondisi bisnis dan faktor eksternal lainnya;

4) Dengan demikian BUMD terbuka berdasarkan self assestment tersebut diatas secara umum merupakan bank Sehat. Hal ini diperkuat oleh peringkat komposit tingkat kesehatan BUMD terbuka berdasarkan hasil self assessment tidak memiliki perbedaan dengan hasil penilaian dari Otoritas Jasa Keuangan.

5) Berdasarkan credit rating dari Pefindo dan data historical penerbitan surat utang, BUMD terbuka merupakan bank yang dapat dinyatakan kuat.

Berdasarkan hasil analisis kelayakan keuangan, portofolio dan risiko tersebut diatas, maka dapat dipertimbangkan penambahan setoran Modal Pemerintah Daerah kepada BUMD terbuka dalam rangka penguatan fiskal Daerah, apabila tidak melakukan penyertaan modal sesuai dengan porsinya maka akan terdilusi kepemilikan saham Pemerintah Daerah pada BUMD terbuka. Pengawasan oleh pemegang saham khususnya pemegang saham mayoritas harus lebih intensif, menghindari adanya risiko financial loss yang material. Jika Pemerintah Daerah mempertimbangkan akan melakukan Penempatan Modal Daerah dalam 2 (dua) tahap di Tahun Anggaran 2018 dan 2019 yang dikarenakan oleh kemampuan keuangan daerah, maka pada tahun 2019 harus dianggarkan untuk pendanaan Kantor Jasa Profesi Penilai/KJPP (untuk menilai harga saham tahun berkenaan). Selanjutnya, jika dianggarkan untuk tahun anggaran 
2019 dan 2020, di tahun 2020-pun harus dianggarkan untuk pendanaan KJPP. Jika kemampuan keuangan daerah memadai, seyogyanya dilakukan dengan 1 (satu) kali penempatan modal daerah.

Setelah kajian-kajian dilakukan oleh beberapa lembaga/instansi terkait, dilakukan sosialisasi hasil kajian investasi dan kajian hukum terkait penyertaan modal dengan mengundang seluruh Pemerintah Daerah Pemegang Saham. Sesuai Peraturan Menteri No. 52 Tahun 2012, didalamnya memuat hasil analisis investasi mengenai hasil kajian investasi dan kajian hukum yang dilakukan oleh Tim Penasihat Investasi Pemerintah Daerah. Hasil tersebut dijadikan rujukan oleh Pemerintah Daerah lainnya, dengan cara menundukan diri secara sukarela yang dituangkan dalam keputusan Bupati atau walikota.

Berkaitan dengan PMT HMETD, harus dilakukan taksasi terlebih dahulu terkait dengan penilaian harga saham wajar oleh Kantor Jasa Profesi Penilai/KJPP (untuk menilai harga saham tahun berkenaan). Sehingga KJPP melakukan kajian terhadap nilai harga wajar untuk BUMD terbuka. Selanjutnya diselenggarakan RUPS untuk menentukan nilai harga pelaksanaan per lembar saham. Harga pelaksaanaan penerbitan saham baru tersebut berdasarkan ketentuan dalam Peraturan Pencatatan BEI Nomor A1 Keputusan Nomor Kep-00001/BEI/012014 pada tanggal 20 Januari 2014, mengatur bahwa penentuan harga saham ditetapkan tidak lebih rendah dari harga saham ratarata (kenaikan dan penurun) selama 25 hari bursa sebelum penutupan perdagangan saham perseroan di BEI. Dilihat dari harga saham rata-rata perseroan BUMD terbuka (kenaikan dan penurunan) selama 25 hari penutupan perdagangan saham perseroan di BEI, ditetapkan bahwa harga saham tidak lebih rendah dari Rp 1.900 (seribu sembilan ratus rupiah) per lembar saham.

Keputusan menerbitkan saham baru telah diputuskan dalam Rapat Umum Pemegang Saham Luar Biasa (RUPSLB) tahun 2018. Pihak yang berhak mengambil bagian dari saham seri A tahun 2018 akan melakukan penyetoran dengan menggunakan APBD tahun 2018 sampai dengan APBD tahun 2020. Sebagian pelaksanaan penerbitan saham dilakukan pada tahun 2018, dan sisanya akan dilakukan paling lambat dua tahun sejak RUPSLB atau tahun 2020. BUMD terbuka akan mengumumkan melalui situs web Bursa Efek Indonesia dan situs web Perseroan 14 (empat belas) hari sebelum pelaksanaan penerbitan saham Seri A dalam rangka Program Penambahan Modal 
Tanpa HMETD ini, dan melaporkan paling lambat 2 (dua) hari setelah realisasi penerbitan saham seri A.

Dari sejak diputuskan dalam RUPSLB sampai dengan saat ini, pelaksanaan penerbitan saham baru atas keputusan RUPS LB melalui program PMT HMETD baru $40 \%$ dari total rencana penerbitan lembar saham baru dengan harga penerbitan sebesar Rp 1.900,- (seribu sembilan ratus rupiah) per lembar saham. Sepanjang tahun 2019 dan 2020, sampai dengan saat ini belum terdapat tambahan setoran modal yang diefektifkan karena salah satu poin dalam kajian hukum mengenai harga pasar dimana apabila harga saham di bursa efek Indonesia pada saat akan dilakukan penempatan berada dibawah harga saham yang disetujui/ditetapkan dalam RUPS, maka sebaiknya Pemerintah Daerah menunda terlebih dahulu penyertaan/ penempatan modal. Harga pasar di bursa efek selama periode tahun 2019 sampai dengan 2020 tidak menyentuh minimum harga penerbitan Rp 1.900,- (seribu sembilan ratus rupiah) per lembar saham, meskipun dalam regulasi yang berlaku di pasar modal eksekusi dari program PMT HMETD cukup mengacu pada hasil keputusan RUPS tanpa melihat harga pasar, namun sebagai bentuk kehati-hatian, persyaratan yang tercantum dalam kajian hukum tetap dipertimbangkan dalam pengefektifan setoran modal melalui mekanisme PMT HMETD ini.

Tidak optimalnya eksekusi dari program PMT HMETD sepanjang periode 2 (dua) tahun sejak RUPS LB tahun 2018 sampai dengan saat ini terkait dengan harga pasar berdasarkan hasil evaluasi dipicu juga antara lain kondisi perekonomian global dan nasional pada tahun 2019 serta diperburuk dengan terjadinya pandemi covid-19 sejak awal tahun 2020 memiliki imbas terhadap penurunan Indeks Harga Saham Gabungan (IHSG) yang berdampak pada ketidakcapaian harga pasar saham BUMD terbuka sebagaimana disetujui dalam dalam RUPS. Atas belum tercapainya rencana penambahan modal tersebut secara optimal, berdampak terhadap rasio permodalan yang tidak tumbuh sesuai dengan rencana perusahaan untuk mendukung ekspansi bisnisnya. Sedangkan dari pihak Pemerintah Daerah selaku investor yang setoran modalnya tidak terealisasi memiliki dampak terdilusinya porsi kepemilikan sahamnya serta tidak optimalnya penyerapan APBD.

Berdasarkan pembahasan di atas, terlihat bahwa tidak efektifnya pelaksanaan program PMT HMETD oleh BUMD berstatus perusahaan terbuka disebabkan oleh adanya ketidakpastian hukum karena aturan yang berlaku untuk investasi Pemerintah Daerah belum mengakomodir BUMD dengan status perusahaan terbuka, sehingga 
untuk aturan yang masih belum jelas mengenai hal tersebut perlu dijembatani oleh berbagai kajian termasuk aspek hukum. Sebagai alternatif upaya peningkatan permodalan, hal yang bisa dilakukan oleh BUMD berstatus perusahaan terbuka adalah dengan melakukan aksi korporasi penambahan modal melalui mekanisme Hak Memesan Efek Terlebih Dahulu (HMETD), mengingat berdasarkan POJK 14 tahun 2019 tentang Perubahan atas Peraturan Otoritas Jasa Keuangan nomor 32 tahun 2015 tentang Penambahan Modal dengan Memberikan HMETD atau Right Issue, pengefektifan dana setoran modal kini dilakukan paling lambat satu tahun sejak keputusan RUPS sehingga Pemerintah Daerah memiliki waktu yang cukup untuk penyusunan kajian dan peraturan daerah yang diperlukan. Sedangkan dari sisi investor dalam hal ini Pemerintah Daerah hal yang dapat dilakukan adalah dengan mendorong Kementerian Dalam Negeri untuk melakukan pembaharuan hukum atau harmonisasi regulasi yang mengatur Investasi Pemerintah Daerah dengan aturan yang berlaku di pasar modal untuk sebuah aksi korporasi peningkatan permodalan melalui penerbitan saham baru.

\section{PENUTUP}

\section{Kesimpulan}

Terdapat unsur ketidakpastian hukum dalam pelaksanaan program penambahan modal melalui mekanisme PMT HMETD bagi BUMD berstatus perusahaan terbuka karena regulasi dalam Investasi Pemerintah Daerah yang belum mengadopsi aturan yang berlaku umum di pasar modal sehingga diperlukan adanya kajian kajian lain seperti kajian aspek dan kajian aspek keuangan daerah untuk meminimalisir adanya risiko hukum khususnya bagi Pemerintah Daerah sebagai investor.

Bagi BUMD berstatus perusahaan terbuka diperlukan adanya solusi untuk pemenuhan kebutuhan permodalannya, sehingga bisa terus melakukan ekspansi usaha dan memberikan kontribusi lebih besar bagi pendapatan asli daerah. Salah satu nya bisa melakukan aksi korporasi penambahan modal melalui mekanisme dengan Hak Memesan Efek Terlebih Dahulu (HMETD), mengingat berdasarkan POJK 14 tahun 2019 tentang Perubahan atas Peraturan Otoritas Jasa Keuangan nomor 32 tahun 2015 tentang Penambahan Modal Perusahaan Terbuka dengan Memberikan HMETD atau Right Issue, pengefektifan dana setoran modal dilakukan paling lambat satu tahun sejak keputusan RUPS sehingga Pemerintah Daerah memiliki waktu yang cukup untuk penyusunan kajian dan peraturan daerah yang diperlukan. Sedangkan dari sisi Pemerintah Daerah 
hal yang dapat dilakukan adalah dengan mendorong Kementerian Dalam Negeri untuk melakukan pembaharuan hukum atau harmonisasi regulasi yang mengatur Investasi Pemerintah Daerah dengan aturan yang berlaku di pasar modal.

\section{DAFTAR PUSTAKA}

\section{Buku}

Rokhmatussa'dyah, Ana, Suratman. (2018). Hukum Investasi dan Pasar Modal, Cetakan ke-5. Jakarta: Sinar Grafika.

Mulyana, Dedy. (2003). Metodologi Penelitian Kualitatif. Bandung: Remaja Rosdakarya.

Kusumaatmadja, Mochtar, Sidharta, B. Arief. (2000). Pengantar Ilmu Hukum Suatu Pengenalan Pertama Ruang Lingkup Berlakunya Ilmu Hukum - Buku I. Bandung: Alumni.

Djumhana, Muhammad. (1994). Hukum Ekonomi Sosial Indonesia. Bandung: Citra Aditya Bakti.

Salman, Otje, Damian, Eddy. (2011). Kumpulan Karya Tulis: Mochtar Kusumaatmadja Konsep-Konsep hukum dalam Pembangunan, Bandung: Alumni.

Soekanto, Soerjono. (2007). Pengantar Penelitian Hukum. Jakarta: UI Press.

Soekanto, Soerjono, Mamudji, Sri. (2009). Penelitian Hukum Normatif. Jakarta: PT. Raja Grafindo Persada.

Sjahdeini, Sutan Remy. (2016). Sejarah, Asas, dan Teori Hukum Kepailitan. Jakarta: Kencana.

\section{Jurnal}

Alim Mustofa, Hendry Cahyono. (2014). “Analisis Kontribusi Pasar Modal sebagai Sarana Pendanaan Usaha bagi Perusahaan serta multiplier Effect yang ditimbulkannya dalam perekonomian", Jurnal Pendidikan dan ekonomi UNESA, Vol. 2 No. 3.

Bagus Sujatmiko, Nyulistiowati Suryanti. (2017). "Perlindungan Hukum bagi Investor pada Perusahaan Terbuka yang Pailit Ditinjau dari Hukum Kepailitan", Jurnal Bina Mulia Hukum, Vol. 2 No. 1. 


\section{Peraturan Perundang-Undangan}

Undang-Undang Dasar Republik Indonesia Tahun 1945.

Undang-Undang Nomor 8 tahun 1995 tentang Pasar Modal.

Undang-Undang Nomor 10 Tahun 1998 Tentang Perubahan Atas Undang-Undang Nomor 7 Tahun 1992 Tentang Perbankan.

Undang-Undang Nomor 40 Tahun 2007 Tentang Perseroan Terbatas.

Undang-Undang Nomor 23 tahun 2014 tentang Pemerintahan Daerah.

Peraturan Pemerintah Nomor 54 Tahun 2017 tentang Badan Usaha Milik Daerah.

Peraturan Menteri Dalam Negeri Nomor 52 Tahun 2012 Tentang Pedoman Pengelolaan Investasi Pemerintah Daerah.

Peraturan Otoritas Jasa Keuangan Nomor 14/POJK.04/2019 Tentang Perubahan Atas Peraturan Otoritas Jasa Keuangan nomor 32/POJK.04/ 2015 Tentang Penambahan Modal Perusahaan Terbuka Dengan Memberikan Hak Memesan Efek Terlebih Dahulu.

Peraturan Otoritas Jasa Keuangan Nomor 32/POJK.04/2015 Tentang Penambahan Modal Perusahaan Terbuka Dengan Memberikan Hak Memesan Efek Terlebih Dahulu.

\section{Sumber Lain}

Jogloabang. (2019). PP 54 Tahun 2017 tentang Badan Usaha Milik Daerah. Available Online From: https://www.jogloabang.com/ekbis/pp-54-2017-badan-usahamilik-daerah. bank bjb. Keterbukaan Informasi. Available Online From: https://bankbjb.co.id/images/dynamic/images/galeri/19110060/19110334_(U pdate \%20Setelah\%20Publish)\%2004\%20Keterbukaan\%20Informasi\%20PMTHME TD\%20v15.pdf

Bank bjb. (2018). Laporan Pelaksanan Penerbitan Saham Seri A Baru Dalam Rangka Penambahan Modal Tanpa HMETD. Available Online From: https://www.bankbjb.co.id/tentang/eng/berita-dan-media/berita/2018-12-28487-laporan-pelaksanaan-penerbitan-saham-seri-a-baru-dalam-rangka penambahan-modal-tanpa-hak-memesan-efek-terlebih-dahulu. 